\title{
Methodological Guidelines for the Use of Geoprocessing Tools: Spatial Analysis Operations-Kernel, Buffer and the Remote Sensing Image Classification ${ }^{1}$
}

\author{
Christian Nunes da Silva, João Marcio Palheta da Silva, Carlos Jorge Nogueira Castro \\ Federal University of Pará, (UFPA), Belém, Brazil \\ Email: cnunes@ufpa.br, jmpalheta@ufpa.br, carlosjorge319@yahoo.com.br
}

Received 24 March 2015; accepted 21 July 2015; published 24 July 2015

Copyright (C) 2015 by authors and Scientific Research Publishing Inc.

This work is licensed under the Creative Commons Attribution International License (CC BY).

http://creativecommons.org/licenses/by/4.0/

\section{(c) (i) Open Access}

\section{Abstract}

The so-called geotechnology has been used in recent years in the planning, supervision and monitoring of various human activities, both locally and regionally, nationally and internationally, either it in the rural environment, as in urban áreas. This study, based on references and activities in the Geographic Information Analysis Laboratory of the Federal University of Pará (LAIG/UFPA), selects and presents the application of three tools for spatial analysis available in the Terraview [1] and Arcgis softwares, with the main objective being to demonstrate how they can be applied in geographical studies, starting with the spatial information gathered by remote or Field sensors, assisting the activities of researchers who stick to working with the planning and management of natural and human resources. Geotechnologies are important tools in the analysis of geographic space and its use tends to be increased with the advancement of new software and hardware collection, manipulation and generation of new specialized information. So we will do in this manuscript a brief discussion of three spatial analysis tools that can be used in rural areas with agricultural potential.

\section{Keywords}

Geotechnology, Geoprocessing, Spatial Analysis

\footnotetext{
${ }^{1}$ Article coming from the discussions held during the implementation of the project "Participatory Mapping and survival strategies by traditional populations in Amazon/Pará", approved in Notice 14/2013 (Universal Call-MCTI/CNPq) and coordinated by Prof. Dr. Christian Nunes da Silva. 


\section{Introduction}

In recent years, noting the activities undertaken by public agencies and private enterprises, it can be seen that the geotechnologies (remote sensors, equipment and geospatial technologies, global positioning system, geographic information systems, etc.) are still poorly-used tools for the management of natural resources in the Brazilian Amazon. These cartographic technologies are effective in aids management, environmental monitoring and oversight of the government (federal, state and municipal), and the application potential of the private sector. It is apparent that some parameters and global positioning techniques and remote sensing are already widely used in the monitoring and management of agricultural activity (as in mechanical harvesting and controlled by satellite positioning) and much of other activities that are carried out in continental areas (such as mining, transportation, etc.).

However, we observe that the cartographic products generated by the manipulation of geoprocessing programs are still used only figuratively, for the location in a larger space (as in a situation map), where the critical approach to the objects and phenomena is not discussed and not deepen their spatial analysis through the application of algorithms that can be found in geoprocessing software (kernel, buffer, kriging, Fuzzi logic, Boolean, etc.), which optimize the use of geotechnologies and make spatial analysis an extremely significant tool for planning and management in agricultural areas and their areas of influence.

This study analyzes the application of three spatial analysis tools available in the software Terraview [1] and Arcgis, demonstrating how they can be applied in areas that have agricultural potential, from the spatial information gathered by remote sensors or field, assisting technical activities and researchers who stick to working with planning and land-use planning. It is important to note that in addition to these tools presented here, there are several other spatial operations that can be found in other geoprocessing softwares (commercial and free); it is possible to extract vector or matrix information, with the study based on the linear data, polygonal or specific, such as buffer (area of influence) of the kernel map (estimated intensity point pattern) and remote sensing image classification (to identify the occupation of the ground pattern), which will be demonstrated here. In this sense, we aim to introduce the reader to some examples of how the geotechnologies can be effective tools for agriculture, using as example changes in land use that occur in the Amazon region ${ }^{2}$.

\section{Methodological Procedures}

To carry out jobs like this we seek to realize the potential of so-called geotechnologies, subsidized by the use of software, hardware, etc; specializing in geoprocessing techniques of matrix and vector files, which generate cartographic products of different activities (agriculture, mining, vegetation, soils, fisheries, transport, etc.), and predict phenomena that affect the geographical area and the economy of a region study. In this sense, for the preparation of this text, we used the following procedures:

Initially a survey was conducted and bibliographical research was made in order to discuss themes related to the three tools that have been used (kernel, buffer and the classification and image analysis). The preliminary reading showed us the importance of preparing a text of this kind for those wishing to deepen the potencial of geotechnologies and who wish to build projects and works (monographs, dissertations, theses, projects, reports, etc.), or carry out their profissionals activities supported in the use of these tools;

Subsequently, a survey was conducted on the Internet, locating the cartographic databases that can be used as a source of point and linear data to kernel and buffer procedures that will be presented. For this, the vector information (hydrography and hotspots) were collected from sites that provide to the public the files in shapefile format (.shp extension) that made possible the digital and visual analysis to generate new vector information and matrix from the primary data;

The data points of hotspots [2], available in the .shp format, are characterized by being specific data collected by NOAA-12, NOAA-15, NOAA-16, NOAA-17, NOAA-18, TERRA and AQUA, GOES-10, GOES-12, and MSG-2 sensors, wherein all of the hotspots information of these sensors were processed by the National Institute for Space Research [2] and made available to the public through the website of this institution. In specific data about hotspots was applied a tool known as kernel function, which is processed by Terraview and consists of interpolating an intensity value for each cell of a grid from a given point, given a symmetric function centered in the cell, which is used to calculate the points located within a certain distance from the center of the cell, gene-

\footnotetext{
${ }^{2}$ The authors of this text do research in this area for nearly 20 years, a fact that motivated and influenced the choice of this study area.
} 
rating an intensity at the end of the array [3]. When the matrix is generated informing the kernel map of hotspots, the vector file from the state of Pará was overlaid with $100 \%$ transparency in its completion, to verify the municipal area where greater incidence of hotspots occured during the study period;

The linear vector data on hydrography, in vector format (.shp), were purchased from the Remote Sensing Center site of the Brazilian Institute of Environment and Renewable Natural Resources-CSR/IBAMA [4]. In these, was applied a tool known as buffer that shows to the user the area of influence of the main theme (in this case, hydrography) that, together with the defending Brazilian law, can show the user the location of Permanent Preservation Areas-APP, as will be demonstrated later;

For the analysis of remote sensing images, which supported the temporal analysis in the laboratory, was selected an area in the municipality of Breves (Pará, Brazil), which corresponds to a Conservation Unit (UC), where it was decided, as starting point, 1999 [5], reaching 2008, subsequently to the creation of a Conservation Unit (UC) in that region. To allow the interpretation, classification and analysis of the images to be possible, 4 pictures of different years were worked with (orbits 224 and 225, paragraph 061), assembled into a mosaic and viewed separately (1999 and 2008) ${ }^{3}$, which enabled the identification of 5 geoclasses (bodies of water, cloud, vegetation, bare soil and shaded area), which show the occupancy standards in this Extractive Reserve (RESEX).

Finally, cartographic products were generated (maps, geographic database, cartograms), which serve as a model and subsidized space operations presented in this article. However, a brief conceptual discussion of what we understand about the so-called geotechnologies is necessary, to further support the reader in the discussion of the applicability, which will be shown in later chapters.

\section{Geotechnologies and GIS}

With the technical-scientific and informational advancement [6] the need to obtain information about the position, the area or the distance of a particular location, object or phenomenon (buildings, streets, highways, towns, farms, cities, regions, states, ports, etc.), increased considerably; and the speed with which this information was processed surpassed the systems and methods previously used [7]. Thus, the geotechnologies, arising from the technological evolution of remote sensing, data processing electronically and the popularization of equipment such as the Global Positioning System (GPS), scanner, printers, personal computers, etc; with settings and supportive software for processing large amounts of information, then resolved most of the time problems, lack of skilled technicians and precision on the amount of information generated by maps.

Therefore, the use of such geotechnologies, combined with spatial analysis methodologies can support decision-making by the government in land use planning at the local, regional or national and even international scale. In the case of this study, the use of a Geographic Information System-GIS, as Terraview, have fundamental importance, as this allows software, among other things " $(. .$.$) to enter and integrate in a single database, spa-$ tial information data generated from a variety of sources", and "(...) offering mechanisms to match the various information through manipulation and analysis algorithms, as well as to query, retrieve, view and plot the contents of the database georeferenced" [8]. Thus, a GIS today, because it is a tool that helps many professionals, is of great importance from the moment we can work with various information (land use, hydrology, roads, geology, geomorphology, etc.) in the same Geographic Database (BDG).

Figure 1 demonstrates how well we understand the steps that make up the GIS used in this article.

Thus, the GIS is seen as a major space technology (or geotechnology), which integrates a variety of information and extend these techniques to several other human activities. In this way a BDG created allows to enter and integrate spatial information from different sources, such as field survey, remote sensing images, tabular census data and records; and offers tools for managing this information (query, view, update, edit, and plotting).

\section{The Kernel MAP for Estimate of Heat Foci of Specific Standards of Intensity ${ }^{4}$}

The kernel function may be defined as a method and/or process where the final product will allow the user to view the intensity pattern of object points on the Earth's surface [3], i.e. an estimated intensity occurring given

\footnotetext{
${ }^{3}$ In carrying out this multi-temporal analysis, we used images of the Thematic Mapper sensor, aero embedded in the Landsat 5 satellite, available at INPE website (www.inpe.br). Scenes of orbits-point 224/225-061 of this sensor, which make up Figure 5, were processed in Terraview and Arcgis software and further development of graphics with the area calculation in Microsoft Excell software (Figure 6). ${ }^{4}$ To view this spatial analysis methodology selected the Pará state area (Brazil).
} 


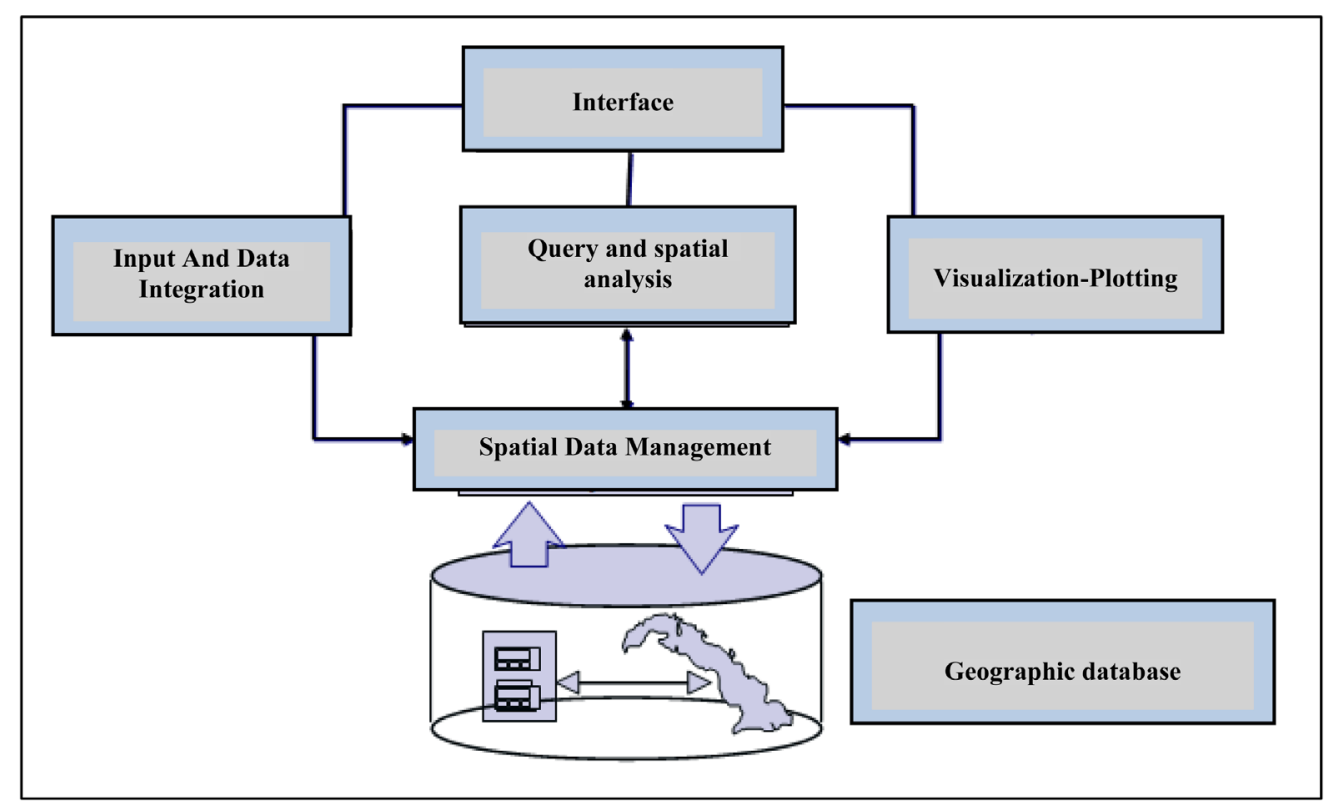

Figure 1. Overview of GIS (source: [8]).

object-precisely, in this case the hot spots, previously identified through images of interpretations collected by remote sensors [2]. According to Santos and Assunção [3], the kernel is a function that associates a value to a point of the study area based on the distance of each neighbor event to it, so the neighborhood criterion is defined by the user, which determines the amount of smoothing. In this sense, the kernel function is for Câmara and Carvalho [9]: "The simplest and most usual form is made by setting a two-dimensional function with the considered event, forming a surface whose value is proportional to the intensity of events per unit area. This function performs a count of all points within a region of influence, weighting them by the distance of each to the point that is being estimated".

Figure 2 illustrates the comment in which Câmara and Carvalho [9], demonstrate the kernel function:

In practice, with the point estimate intensity is possible to map any point events, thus generating the verification of the intensity of the events. Câmara and Carvalho [9] featuring "events" as any phenomenon that can be located in an area and also point out that these points are not associated with values, some may be associated with identifying attributes. The advantage in using the kernel function is the easy viewing of the most critical locations through color intensity.

Thus, the kernel function provides the spot intensity throughout the study area and it is possible to see the most critical areas. Although apparently a simple analysis on a large scale, when applied in medium and small cartographic scales as 1:500,000 or 1:1,000,000, the capability of the kernel function shows importance (Figure 3 ). This method does not relate quantity versus quality, it analyzes only one point and not a relational phenomenon that for a wide application area it seems effective.

In Figure 3, one can verify hotspot identification", or "hot spots", according to the places where the concentration of the phenomenon or process is more intense. So, the kernel function study of the area demonstrates the intensity of spatial events, based on a simple implementation of data structure-from 0 to 155 , which represents the density calculation of specific patterns observed in the field [10], in this case, specific standards derived from the identification of hot spots, a total of 22,552 outbreaks in September 2011 for the entire state of Pará. In Figure 3(b) it appears that there is an orderly pattern, systematic that is not randomly distributed in a region, but are placed in places where there are activities that make greater use of fires in rural areas, where, depending on the regional importance of these locations, monitoring and supervision should happen more strongly, that is, in agricultural and/or forest areas.

In Figure 3, for the analysis of map kernel, we see the range of blue color (cyan), with value 0 to 19:38, from

\footnotetext{
${ }^{5}$ Also means the access point or extension point and can relate to many areas of the map, depending on the concentration and intensity of events.
} 


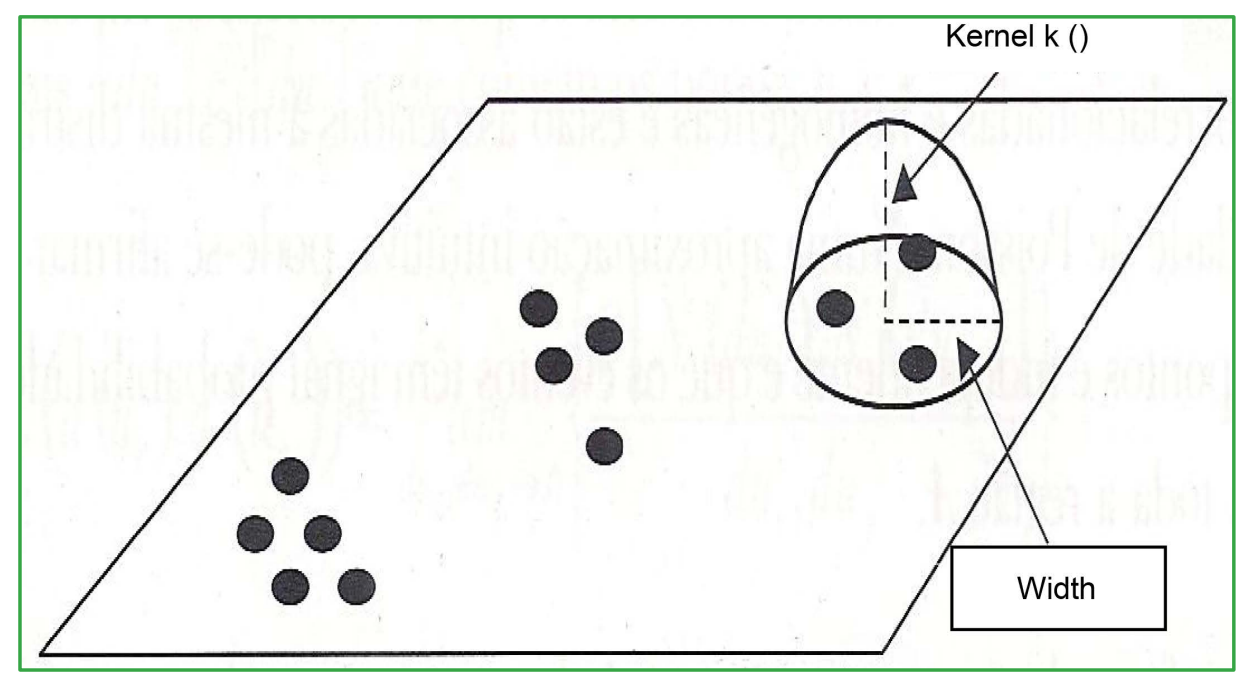

Figure 2. Estimator of intensity distribution points (source: [9]).

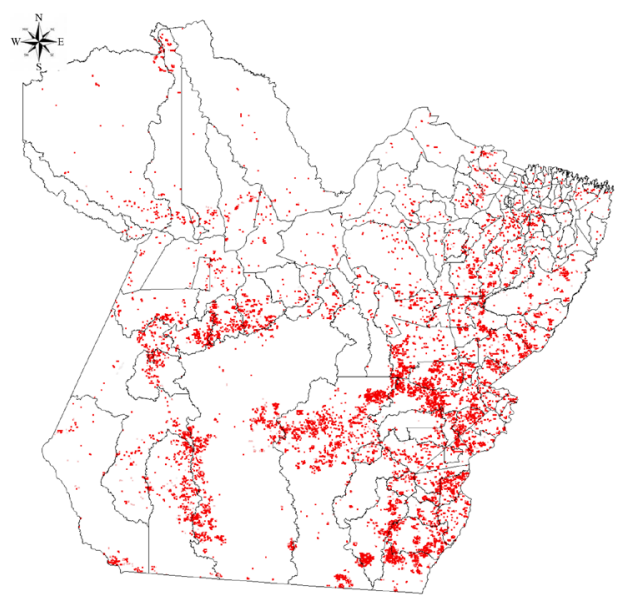

Situation

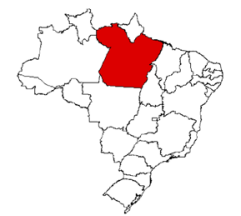

(a)

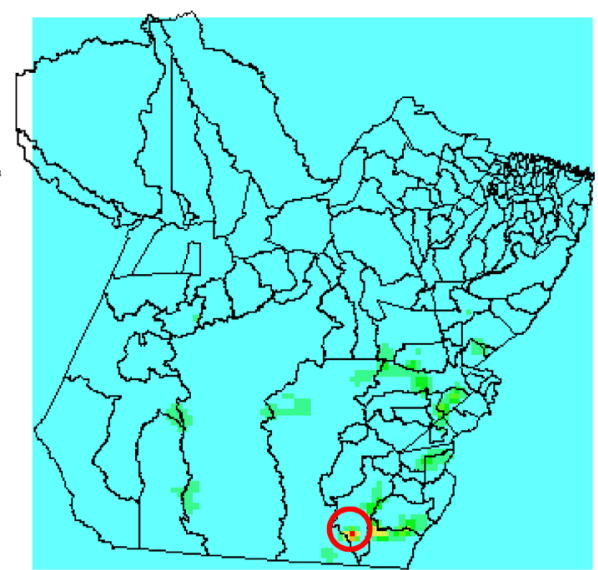

$-0.01 \sim 19.38$

$19.38 \sim 38.75$

$38.75 \sim 58.13$

$58.13 \sim 77.50$

Legend

Kernel Values

$77.50 \sim 96.88$

$96.88 \sim 116.25$

$116.25 \sim 135.63$

135.63 155.01

(b)

Figure 3. Kernel Analysis: Density Estimation of point patterns-Spotlights Heat in the state of Pará (Brazil) (source: Cartographic product generated from data hot spots [2]).

the green hue (19:38 to 77.50), which correspond to places where there is less heat sources (blue and green), advancing to the red (77.50 to 155.01 ), to the places where there are more outbreaks (from orange to red), respectively. In this case in particular, the data demonstrate that the highest concentration of hotspots in September 2011 took place in the south-southeast Pará region, with a focus summit for the city of North Cumaru, where there was an intensification of hotspots that month (highlighted in red circle in Figure 3(b).

Thus, the kernel method is recommended for the preparation of cartograms, maps, charts and plans, however, we must pay attention to the lack of precision in the graphic reality of Earth's surface, since the information is available in matrix grid, that ignores the "contours" of where the events are processed. Regarding the use of this type of analysis, we can cite other studies that use the kernel for spatial analysis of events, as in Carneiro; Santos 
[11], for the study of location of endemic diseases outbreaks; Souza-Santos and Carvalho [12] in the detection of dengue outbreaks; Silva and Sadeck [13], in fisheries studies and Alvarez [14], checking incidence areas where crimes occur in the urban area of a municipality Pará (Brazil).

\section{Delineation of Areas of Influence (Buffer) for the Analysis of Permanent Preservations Areas-App}

As stated previously, in identifying areas of influence of a particular object or phenomenon you can use the so-called buffer tool, which is available in most GIS (commercial and free). This tool allows the user to define the areas of influence of an object, which can be any type of spatial representation in vector format (point, line or polygon).

To illustrate the use of the buffer will resort to saying the Brazilian Forest Code [15], for the definition of Permanent Preservation Areas-APP. Understood as: “(...) permanent preservation area: protected area in accordance with Articles $2^{\circ}$ and $3^{\circ}$ of this Law, covered or not by native vegetation, with the environmental function of preserving water resources, landscape, geological stability, biodiversity, gene flow of fauna and flora, soil protection and ensure the well-being of human populations" [15].

These areas are characterized as dunes, top of hills and mountains, mangroves, salt marshes, springs, riparian forests, among others. In the case of APP that border water bodies, the legislation requires to be preserved according to the width of the river or stream, if not, the environmental services generated by this environment may be compromised by sedimentation, for example. Thus, the Brazilian Forest Code indicates the measures to be fixed for the APP along the banks of water bodies, according to their average width.

Thereby we can understand APP as an area of influence from a river, for example, that should be preserved to maintain a protected environment without impairing its operation. In our case, the GIS software can generate a buffer based on the Forest Code determines, asserting the limits of rivers, as follows: We assume that we need to delimit the area of influence of a number of water bodies in an environment of island, and these streams have an average width of 10 to 50 meters, then following what says the Brazilian Forest Code [15], the area to be preserved shall be 50 meters.

By using the Terraview program, it is possible to define the APP in an automated way, to create a buffer which is available via plug-in software. So what we see in Figures 4(a)-(c) are 3 different views in the identification of APP. In Figure 4(a), we highlight the study area, an island setting with bodies of intra-island water, identified by the color blue, in linear format; in Figure 4(b), we observe the definition of the catchment area of 50 meters, for all water bodies that are part of the island region. In Figure 4(c) there is an expansion of the area of interest, showing the river (in blue), and its area of influence (in red), as identified by the buffer creation in Terraview.

It is important to mention that the buffer allows the user to quickly identify the area of influence of several human activities that affect not only the APP, but also has a direct impact on communities affected by human works (agriculture, roads, industries, power plants, etc.), polluting activities (landfills), areas of occurrence of

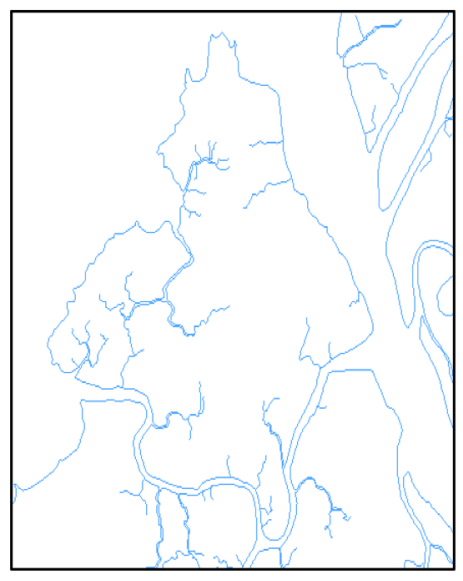

(a)

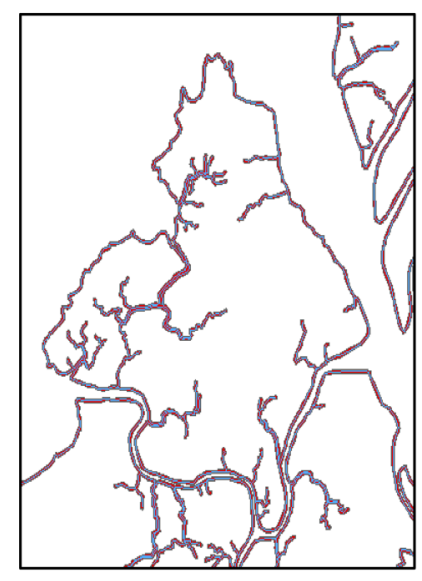

(b)

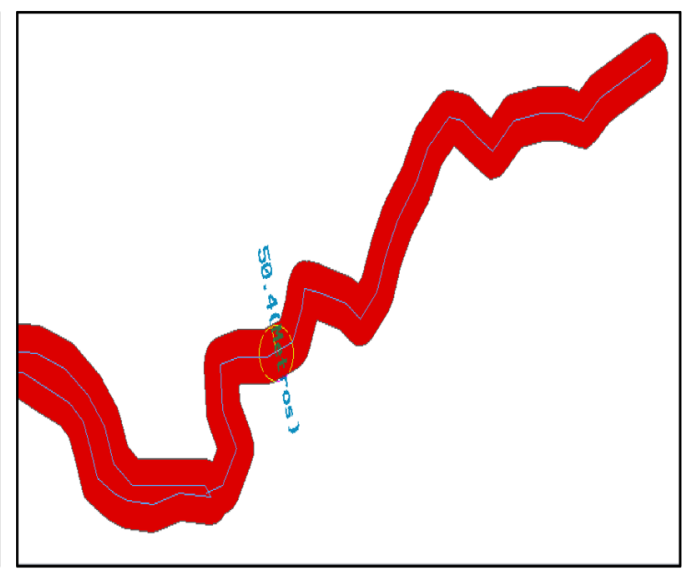

(c)

Figure 4. Preparation of a buffer for the delimitation of areas of influence (source: Cartographic product generated from deriving the cartographic database of the CSR [4]). 
diseases, crime, etc. Therefore, the work to be performed with this tool can be diverse, and rely heavily on the professional who uses this technique, for example, the work Moraes et al. [16], which discuss the use of GIS in the spatial distribution of remaining forest fragments in watersheds; the study of Bernini; Oliveira; Moret [17], which analyzes the use of natural resources in protected areas; amongst others that use this spatial analysis methodology.

\section{Classification and Analysis of Remote Sensors Images ${ }^{6}$}

The Remote Sensing (RS) enables the achievement of remote sensing images of a given portion of the earth's surface, away from the user. However, obtaining this type of image depends on the used remote sensor and electromagnetic radiation (EMR) from the wavelength emitted by the sensor that reaches the target (area) and interacting with the imaged object, and this reflected energy that sensor captures in spectral bands [18] [19]. The matrix digital image can be established in different color spaces, among these, is the RGB system ${ }^{7}$, where the composite images can be worked on GIS for the interpretation and analysis of the products generated ${ }^{8}$. Recognize the spectral signatures of targets enables us a interpretation of the images, for selecting a part of the study area, then the Resex Mapuá in order to recognize the physical and anthropogenic features present in their occupation.

As a result of processing of images collected from the study area, the disturbed sites have magenta; areas with arboreal vegetation tend to dark green; areas of scrub vegetation to pale green; the exposed soil areas tend to shades of orange tones in red, areas that have undergone burning processes tend to have a violet tint in the processed image.

As for the process of exploitation of natural resources, developed in the communities of RESEX Mapuá, there is the small-scale agriculture in upland and lowland, besides the exploitation of native production systems whose main activity plant extraction açaí, hearts of palm, fruit [20]. This exploration emerges from the need to acquire income and livelihood of these families, so it can be said that it is an activity that is of fundamental importance to the community's dynamism, as verified by Arima; Maciel and Uhl [21], when focus on the wealth of natural resources, which is an important factor for the maintenance of life of the inhabitants of the Amazon estuary and have a significant economic importance to the livelihood of families (wood, fish, fiber, between others), provided that used rationally [21] [22].

In Figure 5, can be verified the classification and multitemporal analysis of the use and occupation of RESEX Mapuá in a time period of 10 years.

The images in Figure 5 show the use of the land over the years 1999-2008. In it is observed that there were no significant changes in land use, since the natural area still remains well preserved, which justifies the creation of RESEX Mapuá. It was verified in the field, as already discussed, that the activities reflecting in deforestation or land cover type of modification are mainly directed to the production of agriculture and animal husbandry of small-scale or other activities with low impact on the environmental context in general. In Figure 6 can be verified from the quantitative analysis performed in the classification Figure 5:

Thus, as shown in Figure 6, the areas with vegetation cover (forest or covered area) still remained the same for the analyzed period, in which the exposed soil area decreased by only $1 \%$. A $1 \%$ change in the presence of clouds can also be considered irrelevant compared to the total area of RESEX. The variables remained unchanged for 10 years analyzed fact that shows that there were no significant changes in UC.

The small increase in bare soil area can be directly related to logging in the communities along the river Mapuá because this activity is still one of the main ways of obtaining income of some families. Although commercial logging in RESEX is a very controversial topic, some residents claim that they are using this product for their own account. Anyway, for agricultural activity in other areas the remote sensing image classification methodology appears to be quite effective and is used in conjunction with other tools and positioning satellite tracking in what has been called precision agriculture, already common in some other countries.

The geoprocessing and the classification/analysis of remote sensing images is used in several other studies

\footnotetext{
${ }^{6}$ To view this spatial analysis methodology selected a specific area in order to exemplify its use in this case, the RESEX Mapuá (Pará, Brazil). This UC was established on May 20, 2005 [5], in order to ensure the enjoyment of natural resources to families living in the area, without compromising future generations, following the precepts read in the National Protected Areas System (SNUC).

${ }^{7}$ Abbreviation of Red, Green and Blue.

${ }^{8}$ For the preparation of this article was carried out supervisonada rating due to better organization of spectral signatures in each of certain classes in the sample, which allowed assign the spectral intervals ranging from 0 to 255 in each pixel.
} 


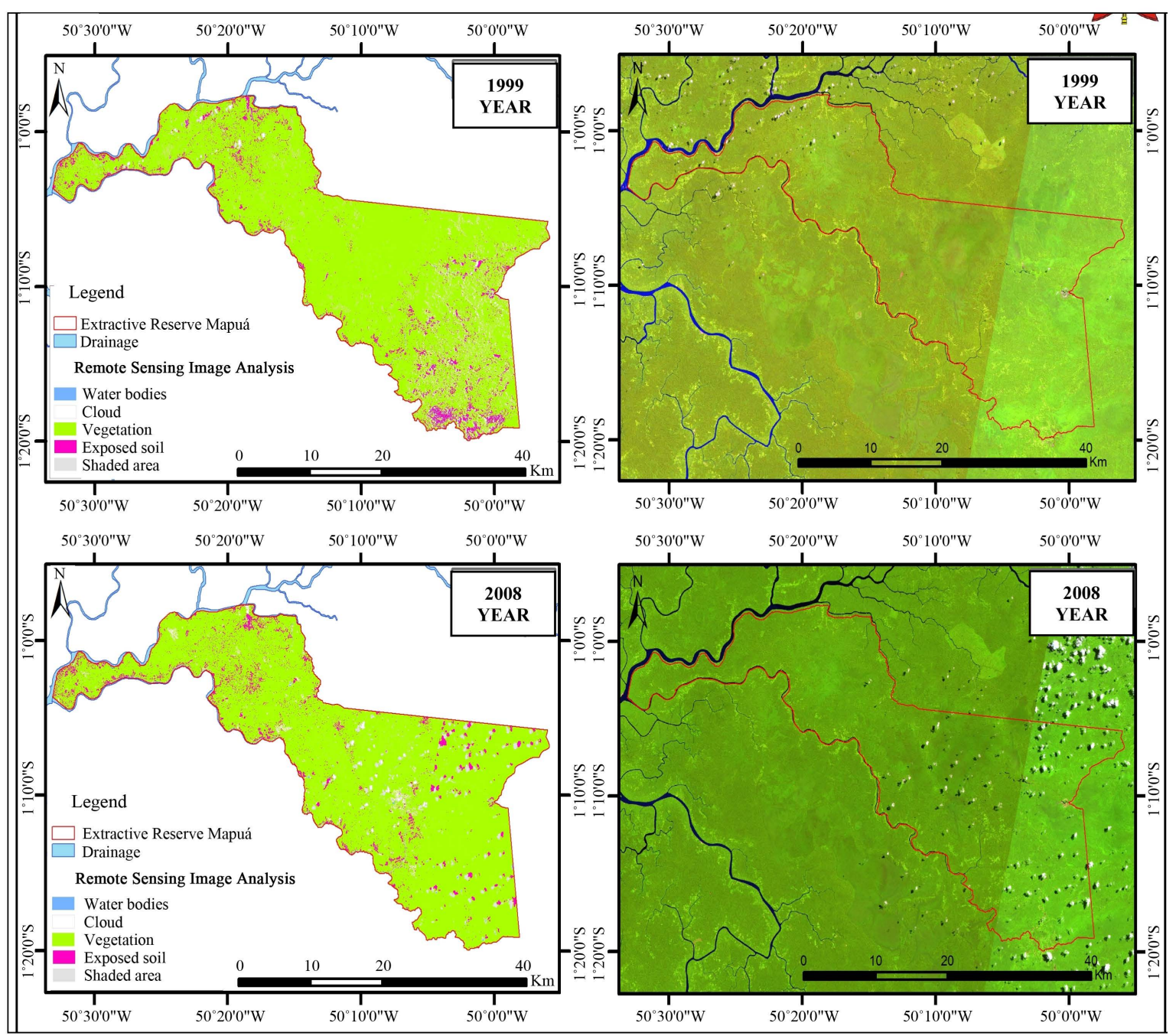

Figure 5. Extractive reserve mapuá: supervised analysis of remote sensing images (1999 and 2008).

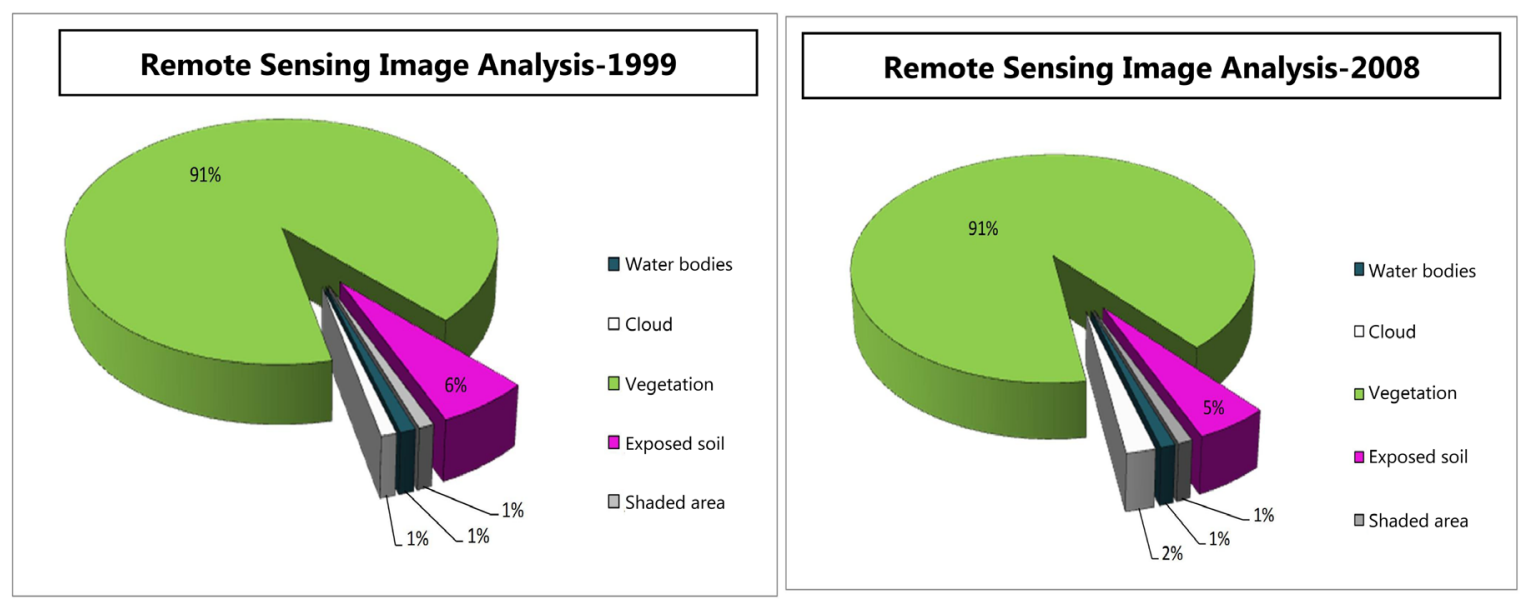

Figure 6. Analysis of remote sensing images (1999 and 2008).

that require a fast processing of large and medium-sized geographic areas, as can be seen in the study of Kouakou and Silva [23], who applied these techniques in the evaluation of geopotential agroterritorial in an African 
country; also highlight the research of Zhang and Baltsavias [24], to improve and update the road database, using image analysis techniques, and the study Batistella, Valladares and Bolfe [25], who used the Landsat images on monitoring of agricultural expansion in the state of Bahia (Brazil).

\section{Conclusions}

Management activities, monitoring and planning the land usage, are examples of how field studies are run with the benefits achieved by the development of so-called geotechnologies. As can be seen throughout the text, the display of spatial information on the computer and its subsequent spatial analysis can be done on a computer by means of extensions and plugins available in geoprocessing and GIS software.

Thereby for the identification of objects and phenomena, and the generation of cartographic products, remote sensing, GIS and preparation of Spatial and/or Geographical Database present with significant potential due to obtain synoptic information, synthesized information of places with difficult access to the user, assisting in the analysis of phenomena and distant processes of the researcher, are of fundamental importance for the (ac)knowledge(ment) of territories with agricultural potential today. Thus, in the case of findings of tools, we point out that:

The analysis of geographical space from the use of spatial analysis procedures used with the kernel function enables a better understanding of spatial phenomena and their intensities. This process allows us to identify some trends that are manifested in geographic space. Thus, in this work, using the Kernel is very significant in the identification of fire outbreaks records, allowing understanding the advance or retreat of an area with fire record, for example.

The development of a catchment area for Buffer is defined according to criteria chosen by the researcher and must comply with study procedures for a given area, according to the information of the Brazilian legislation we use. At Amazon in Pará, these criteria, in general, are also defined in accordance with the dynamics found in a given area, according to the dynamics of the landscape and the activities of the surrounding population and its characteristics.

The remote sensing image classification provides satisfactory results in recognition processes of different textures that can be identified from the processing and manipulation of these images. To perform the image classification it is necessary for the researcher to define what kind of classification methodology that best responds to the objectives of his research and it is also necessary to choose the best sensor for the study in question, according to their spectral, radiometric, spatial and temporal resolutions.

Thus, with the use of fast computers, viewing images and subsequent spatial analysis are performed in a fast and automated way. However, only with the subsequent verification in the field, with the standardization and development of spatial analysis methodologies of the collected data, the final cartographic product will show its importance, because of spot verification and spatial analysis of field data is depending on the veracity of the information contained in the final product, either cartographic or not. Agriculture is one of several activities that can benefit from the use of geoprocessing and its space operations, since the definition or expansion of new agricultural areas becomes more agile and precise in addition to the benefit of retaining financial resources.

\section{Funding}

This research was funded by the Qualified Publication Support Program (PAPQ), offered by the Dean of Research and Graduate Studies (PROPESP) and the Foundation for the Support and Development of Research (FADESP), of the Federal University of Pará.

\section{References}

[1] INPE (Instituto Nacional de Pesquisas Espaciais) (2012) Projeto TerraView. http://www.dpi.inpe.br/terraview/index.php

[2] INPE (Instituto Nacional de Pesquisas Espaciais) (2012) O monitoramento de queimadas e incêndios por satélite em tempo quase-real. http://www.dpi.inpe.br/proarco/bdqueimadas/

[3] Santos, A.A.da and Assunção, R.M. (2003) Uma aplicação de estrutura de dados eficientes na estimação de densidade de eventos espaciais. In: Brazilian Symposium on geoinformatics, 5. Campos do Jordão, Proceedings.

[4] CSR (Centro de Sensoriamento Remoto) (2012) SISCOM—Sistema compartilhado de informações ambientais. 
http://siscom.ibama.gov.br/

[5] Brasil, Presidência da Republica (2005) Decreto de 20 de maio de 2005, que dispõe sobre a criação da Reserva Extrativista Mapuá, no Município de Breves, no Estado do Pará, e dá outras providências, Brasília.

[6] Santos, M. (1996) Metamorfose do espaço habitado. 4th Edition, São Paulo, Hucitec.

[7] Assad, E. and Sano, Eds. (1998) Sistemas de informações geográficas. Embrapa-SPI/ Embrapa-CPAC, Brasília.

[8] Davis, C. and Câmara, G. (2001) Arquitetura de sistemas de informação geográfica. In: Câmara, G., Davis, C. and Monteiro, A.M.V., Eds., Introdução da ciência da Geoinformação, São José dos Campos, INPE, 42-76.

[9] Câmara, G. and Carvalho, M.S. (2004) Análise espacial de eventos. In: Druck, S., Ed., Análise espacial de dados geográficos, Planaltina-DF, Embrapa Cerrados, 53-76.

[10] Paiva, J.C., Rodríguez, A. and Correia, V.R.M. (1999) Métodos computacionais para analisar padrões de pontos espaciais. In: GISBRASIL, 99. Proceedings... Curitiba, FATORGIS.

[11] Carneiro, E.O. and Santos, R.L. (2003) Análise Espacial Aplicada na Determinação de Áreas de Risco para Algumas Doenças Endêmicas (Calazar, Dengue, Diarréia, D.S.T.-Doenças Sexualmente Transmissíveis e Tuberculose), no Bairro de Campo Limpo-Feira de Santana (BA). Sitientibus. Revista da Universidade Estadual de Feira de Santana, Feira de Santana.

[12] Souza-Santos, R. and Carvalho, M.S. (2000) Análise da distribuição espacial de larvas de Aedes aegypti na Ilha do Governador, Rio de Janeiro, Brasil. Cadernos de Saúde Pública, 16, 31-42. http://dx.doi.org/10.1590/S0102-311X2000000100004

[13] Silva, C.N. and Sadeck, L.W. (2011) Geoinformação na atividade pesqueira: uso de imagens de sensores remotos no monitoramento de recursos pesqueiros no litoral paraense. In: Palheta da Silva, J.M. and. Silva, C.N., Org., Pesca e territorialidades: Contribuições para análise espacial da atividade pesqueira, Volume 1, GAPTA/UFPA, Belém, 221239.

[14] Alvarez, W.P. (2011) Geografia e segurança pública: Violência, pobreza e a criminalidade, o uso de sistema de informações geográficas na detecção do crime no município de Marituba. FCG/UFPA, Belém.

[15] Brasil (1965) Lei No 4.771, de 15 de setembro de 1965. Institui o novo código florestal brasileiro, Brasilia.

[16] Moraes, et al. (2001) Técnicas de Geoprocessamento na Definição de Diretrizes de Políticas Públicas para Fins de Planejamento Agroambiental. In: Anais do X SBSR, INPE, Foz do Iguaçu, 947-953.

[17] Bernini, H., Oliveira, D.S. and Moret, A.S. (2007) O uso de geoprocessamento para a tomada de decisão na utilização de recursos naturais: Estudo de caso Resex do Rio Ouro Preto-RO. In: Anais do XII Simpósio de Sensoriamento Remoto, INPE, Florianópolis, 2315-2322.

[18] Fitz, P.R. (2008) Geoprocessamento sem complicação. Oficina de textos, São Paulo.

[19] Silva, C.N. (2013) A representação espacial e a linguagem cartográfica. GAPTA/UFPA, Belém.

[20] Canto, O., Lírio, A. and Ferrão, E. (2009) Ribeirinhos do Mapuá. In: Mota, G., Silva, C.N., Palheta, J.M., et al., Eds., Caminhos e lugares da Amazônia: Ciência, natureza e território, GAPTA/UFPA, Belém, 225-236.

[21] Arima, E.M., Maciel, N. and Uhl, C. (1998) Oportunidades para o desenvolvimento do estuário amazônico. Volume 15, Série Amazônia, Imazon, Belém, 34.

[22] Silva, C.N. (2006) Territorialidades e modo de vida de pescadores do rio Ituquara, Breves-PA. CFCH/UFPA, Belém.

[23] Kouakou, R.N. and Silva, J.X. (2009) Geoprocessamento aplicado à avaliação de geopotencialidade agroterritorial. In: Silva, J.X. and Zaidan, R.T., Eds., Geoprocessamento \& análise ambiental: Aplicações, Bertrand Brasil, Rio de Janeiro, 301-352.

[24] Zhang, C. and Baltsavias, E. (2005) Melhoria e atualização de uma base de dados rodoviários por meio de técnicas de análise de imagens, usando múltiplas fontes de conhecimento e indícios. In: Blaschke, T. and Kux, H., Eds., Sensoriamento remoto e SIG: Novos sistemas sensores-métodos inovadores, Oficina de Textos, São Paulo, 71-83.

[25] Batistella, M., Valladares, G.S. and Bolfe, E.L. (2008) Monitoramento da expansão agropecuária como subsídio à gestão ambiental estratégica na região oeste da Bahia, Brasil. In: Batistella, M. and Moran, E.F., Eds., Geoinformação e monitoramento ambiental na América Latina, Ed. SENAC, São Paulo, 163-195. 